\title{
Special culture and art research authoritarian social structure
}

\author{
Xiumei wu
}

University of jingdezhen ceramic institute of design art, 333403

Keywords: Authoritarian society, special culture, art

\begin{abstract}
Chinese culture has formed the politics-oriented "ethical" paradigm, planted the seeds of the most important, is that it is dependent tyranny of a patriarchal social structure. Generally speaking, patriarchal society is easy to form an ethic culture, and is easy to form politics-oriented culture authoritarian society. China is under the condition of the disintegration of blood ties is not fully formed distinctive patriarchal clan system after entering the class society, and through processing and reformation of rulers and scholars, the formation of the ethics of patriarchal type, long drives people's social psychology and behaviour. The patriarchal social structure not only affects social customs, social psychology, and the role in cultural ideology, such as ethics, morality, religion, values, view of nature, etc., thus forming different from the rest of the world's unique national culture of "ethical" paradigm.
\end{abstract}

\section{The patriarchal social structure characteristics, leading to the Chinese culture form an ethic paradigm}

\section{Patriarchal clan social structure characteristics of the ethical type of chinese culture}

(1). Social psychology, patriarchal clan system of the blood consciousness under the patriarchal ethics, long drives social psychology and behaviour. In the aspect of social psychology, patriarchal structure on the call of the Chinese nation.

First, performance for related notices. Incarnate the fine confused in the relatives appellation system. Second show the strong "XiaoQin" emotion. This kind of emotion is not only embodied in grand shrine to pray for their of deceased ancestors bless offspring into Ding Xingwang, family prosperity, but also embodied in the elders living absolute obedience, filial piety. Filial piety be regarded as the core of all ethical and matrix, such as the statue of king, worship. The final performance in extreme respect for tradition. From the positive ways, respect for tradition of extreme greatly strengthened the composing of Chinese culture, making it the world rare uninterrupted culture system; From the negative side, it also causes the Chinese nation used to look back the tendency of the leopard and conformism, conservative content, thick ancient book today, killing the enterprising and innovative spirit.

(2). Ethics aspect, in order to maintain social members blood ties for duty ethics and its theoretical form, constitute the core of the ideological system of Chinese culture. Said ethics is arguably became the leading culture of the Chinese social category. Ethics is to put people in life habits and customs rules, such as abstract, summary, systematic and theoretical. So a long time people became accustomed to this kind of ethics to restrain themselves, and the statute law is a back, so this kind of ethics in the patriarchal society gradually shape people's thoughts and actions.

The development of the Confucian ethics thought and content: the pre-qin period (21 century BC - 221), YanZhou hitches and the spring and autumn period and the warring states period two stages, is China's production and the formation period, the ethics thought is the Confucian ethics founded period. Han dynasty is an important stage in the history of the development of its, the formation of the "three cardinal guides" is the Confucian ethics on the standardized and systematic stage. Said a new stage of development, Confucian ethics is the neo-confucianism neo-confucianism.

The main content of patriarchal ethics thought is the father love, the son filial piety, friends brother, brother, although these are adjust blood relatives behavior standards, has a strong political function. 
Function of Confucian ethics thought: the Confucian ethics on the one hand, centralized embodies the fundamental interests of the feudal ruling class, is a tool for maintaining the feudal patriarchal hierarchy, on the other hand, is suitable for the needs of the feudal society widespread family system, in the broad by the ruling class in the deep mass base.

(3). In the aspect of morals, the thought of the rule of law in patriarchal society is not as good as man, and man with a special focus on the role of moral enlightenment. Man before the rule of law, a good example is the best sermon is the tradition of patriarchal society.

Three cardinal guides the p5: is the core of the feudal ethics. (dong proposed three cardinal guides "as I outline the father to son, outline, husband to wife outline", "which is" refers to righteousness and propriety wisdom letter, "three cardinal guides said is feudalism ethics approaches, master-slave relations," said is dealing with this kind of human relations code of ethics.) Confucian morality, benevolence, love, take an examination of, loyal, ladder, communication, friendly, sensitive, hui, respect, courtesy, righteousness, wisdom, brave, wide, warm, good, purge, thrifty, make, inexpensive, shame, and so on.

Filial piety: as a moral realm, as advocated by the Confucian and push known, began in the spring and autumn period and the warring states era, and with the development of the feudal society by strengthening, in the feudal society, filial piety became the supreme principle of feudal moral, to safeguard the feudal autocratic rule plays an important role. Filial piety moral become the evaluation of this relationship and parent-child relationships of the code of conduct.

(4) . in view of nature, the unity of nature and of China thought can be divided into the following types: one is the "day" of Confucian ethical significance the thoughts of the unity of people; Second, Taoism has no moral significance of "tao" and unity; Thought. Confucian harmony is divided into two categories: one is originated in mencius, dacheng in Song Mingdao (BSC) between the same thoughts; Second, dong han dynasty between the similar personalities. Thought of common man after can be divided into two groups: one is the so-called represented by zhu xi was appointed in the day, "with the principle as a" thought; The second is the "heart" of represented by wang yangming's thought.

(5). in the aspect of religion, Confucianism in its developing unceasingly absorbs the nutrition of Buddhism, Taoism, enrich their own content, improve their own form. To maintain its mainstream status. Confluence of wei-jin metaphysics and Buddhism; The idealist phylosophy and Buddhism and Taoism into one. Three cardinal guides the p5 ethics played down the religion of the penetration of the national consciousness. The development of religion in China has not been big. Such as: China's indigenous religion, Taoism, Taoist teachings, leader, classic, become a group of religions, in the eastern han dynasty, sui, tang and five dynasties is the golden age in the history of Taoism. The origin of Taoism has 3:1. The ancient ghosts worship; 2 . The fairy magic since the warring states period; 3. The situation of qin and han dynasties. Taoism have many effects on Chinese culture. But it did not reach as Confucianism's dominance.

Buddhism from China in the han. As a foreign Buddhism in wei jin southern and northern dynasties in China can get development because of its faithful in filial, ethical correction is consistent with the Confucian ethics.

\section{Authoritarian features of social structure leads to the formation of a Chinese culture politics-oriented paradigm.}

\section{The formation of politics-oriented paradigm}

In more than two thousand years of autocracy in the social structure, Chinese culture has always been control taken by powerful centralized political power, control, to form a "checking" as the goal of politics-oriented paradigm. Gong zizhen will be summarized as: "the rule of generation, the generation of learning. Also learn one generation, a generation of king of also...., is a mountain, is to learn, also is cure, also is a just." In the shadow of this kind of style, cultural activities have obvious political utilitarian purposes; Cultural achievements is able to count on the protection of power disperse; Literacy - intellectuals arms was unusually strong consciousness of "classic”. 


\section{Under the authoritarian social structure of the characteristics of Chinese culture and political type}

(1) ideological unified Reese recommendation qin shihuang unified the country to establish a "unified dictatorship"; Qin shi huang to unify people thought. A series of cultural measures, such as: book with wen (" books with the word "makes the cultural communication inside the vast territory there will be no language barrier.) With rail, car (convenient from the capital to all parts of the. , degree system (unified standard for economic activity.), with the domain (development frontier. Spread the central plains culture) to form a unified situation.

At the time of emperor wu dong "development" unified "thought" cultural conceptions: namely the cultural despotism, unified thought; The emperor advocated Confucianism, Confucianism. Dong zhongshu put forward a new hold various factors system of Confucianism. Theory of the early han Confucianism from pre-qin scholars and conform to the requirements of society, in order to build an ideal social form again.

Political theory developed [2] Staple of the absolute monarchy theory in China, is the "everything is done in the 3rd century BC, han fei will method (order), surgery (strategy), power (power) three organically. With the continuous strengthening of absolute monarchy political when qin and han dynasties, provide theoretical argument for authoritarian political development continuously. Western han dong make theologize; Create "three cardinal guides" theory of Yin and Yang dong. Divine unity, sovereignty, the patriarchal, absolute monarchy more sacred unshakable; Song dynasty the IQ, cheng cheng and zhu xi, and absolute monarchy socialist neo-confucianism.

Autocratic monarchy in two thousand and the cultural despotism, thick accumulation in the aspect of social psychology. "Noble princes low", is not only a fine theory, theory, and become universally popular social psychology. For infinite fear and obedience of the autocratic monarchy, is China's authoritarian political to continue over a long period of important social psychological factors.

(3) the intellectuals "wto" attitude, "classic" social ambition and absolute monarchy political netting use of intellectuals, intimidation of unity between repression

"A succession of China's accession to wto", established by Confucius Confucianism value orientation, becomes the intelligentsia common life direction. Classic consciousness, desire, is one of the traditional thought becomes the Chinese literary intelligentsia. Intellectuals of this mentality, with absolute monarchy political ideology and regime construction needs. Therefore, firmly control the intelligentsia society "think tank", "talent", at the same time, the government, is the priority for China's authoritarian monarchs. To do this, they skillfully use the netting and intimidation of combining the two policies. Netting, embodied in "can foster learning" voting system, the implementation of the imperial examination system. Shi "and" learning to read a few, is China's monarchy social consensus advocating Confucianism bright future. "' Not smell out of the window, "nature is not to jeopardize the authoritarian political rule. After the sui and tang dynasties." take "on the" official "that can foster" learning "standardized and institutionalized. Reader wants to get ahead, only the poor through, pass civil examinations jinshi huashan one way. This despot passed the imperial examinations, China firmly control intellectuals in his hands. Despot intimidation of intellectuals, is embodied as" was".

\section{The fusion of ethics and politics (pre-qin scholars to Confucian saint outside the king)}

Marriage ethics and politics, is an essential feature of the Chinese culture system, and the formation of this feature has its historical origin. At least since the zhou dynasty. The spring and autumn period and the warring states period, the political turmoil, schools of thought contend. But there are two school school consistent: have high political enthusiasm and attaches great importance to moral and ethical. Political achievement and ethical persuasion is emphasized by the Chinese culture of parallel two core content. It is generally believed that this feature comes from Confucianism.

In the pre-qin period schools of thought contend is mainly around the patriarchal ethics thought. Is essentially a political struggle reflected for each class and class just at the time of the birth of the 
feudal system of different yearning. Confucian filial piety an uniqueness as the core of the patriarchal ethics thought has strong political function. Confucianism of the family system can smooth people's personality, cultivate a submissive character. The Confucian thought, it is this compliant character, the most suitable for the need of national politics. After the emperor, Confucian patriarchal ethics to rise to the dominant ideology, dominate the Chinese feudal society for two dry years, in this phase of a long history, from the point of basic content, there is no change, only in the form of more clear be summed up as three cardinal guides ". Three cardinal guides "which the feudal regime established as the dominant ideology, in terms of the nature and role, fundamental changes have taken place.

The spring and autumn period and the warring states period "schools of thought contend", it is a glorious chapter in the history of Chinese cultural history. For the development of the theoretical system of the Chinese culture, has the decisive planning direction significance. Chinese culture was formed "ethical politics-oriented" cultural paradigm, obviously is closely related to the common features of thought and their exponents.

\section{Conclusion}

The word "inside the saint outside the king" from the "chuang tzu, the world", it in Taoism there is the perfect expression of "doctrine". Although the term is not Confucianism, but Confucianism is certainly Wang Zhidao outside the "internal saints" as the core. Later Confucianism also gradually accepted the term, used to express Confucian ideology. And in the theoretical system of Confucian, there are many similar and the meaning of "inside the saint outside the king" of the term. The pre-qin Confucian doctrine "inside the saint outside the king" germination in the western zhou dynasty, Confucius learned the culture of the zhou dynasty system, system founded the Confucian doctrine "inside the saint outside the king". From Confucius, "internal saints" and "external king" is equally important. After Confucius, mencius school development of Confucius, "internal saints" theory, create the disposition of the Confucian learning, trying to lead directly from "internal saints" "outside the king". Xun zi is from the "outside the king" and developed the Confucius political thought, in an effort to provide feasible theory according to the unified the world. From Confucius, "internal saints" and "external king" is inseparable, "outside the king" is the "internal saints" natural extension, whereas in xun zi, although also advocated "internal saints" and "external king" unifies, but overblown "outside the king", easy to cause "outside the king" and "internal saints" out of line.

Confucianism as an "ethical politics" model theory system, including the inner man's subjective ethical cultivation and external objective political theory of such part of the two connected to each other, the former is referred to as the "benevolence", or "internal saints" of learning, the latter the so-called "the ritual", or "king" of learning. In Confucius, and the two side one integrated mass, he stressed that is well versed with Ann, Ann and the people. After the spring and autumn period and the differentiation within the same school, too. One of the biggest impact was mencius and xunzi. The former focuses on the development of the original Confucianism teaches the "internal saints", which focus on development of Confucianism "outside the king" of the original teaching learning. Of course, mencius and xun zi on both sides are pursuing their inside outside SAN and the unity of the king, is not just one side development in isolation. In a word, after qin and han dynasties, Confucianism along the "internal saints" and "external king" two direction.

\section{References}

[1] xiu-mei wu: the inheritance and change - jingdezhen porcelain development research of the republic of China, Beijing, guangming daily press, 2012, 5.

[2] xiu-mei wu: the traditional handicraft culture research - ceramic hangzhou fan, for example, Beijing: guangming daily press, 2013, 5.

[3] zhen-fan wan, Lin Songhua editor: studies of modern times social transformation in jiangxi, Beijing: China social sciences press, 2001. 
[4] XiChuan performance: "the classical works of design art anthology, nanjing: southeast university press, 2002.

Xiu-mei wu, female, doctor of design art, in fuzhou, master instructor, research direction: the art of design principle, industrial design and theory, ceramic art design and theory.

This paper is the jingdezhen ceramics university center for collaborative project: "jingdezhen ceramic art education from the evolution of modern times to contemporary". 